\title{
Fatigue limit analysis of shot peened spring steel
}

\author{
NohJun Myung ${ }^{1}$, Liang Wang ${ }^{2}$, and Nak-Sam Choi ${ }^{3}$ \\ ${ }^{1}$ Hanyang University - ERICA Campus \\ ${ }^{2}$ Hanyang University - Seoul Campus \\ ${ }^{3}$ Hanyang University
}

January 2, 2021

\begin{abstract}
This paper investigated the effect of shot-peening on fatigue strength of spring steel for the high cycle fatigue (HCF) and very high cycle fatigue (VHCF) to clarify the fatigue limit behavior of high strength spring steel during service life. Hourglass shape specimens made of spring steel (Si-Cr alloys) were prepared for the rotary bending fatigue test. Actual local stresses were quantitatively calculated to compensate for the stress amplitudes, through which it was clarified that the shot-peening had strongly positive effects on the HCF strength, but rather negative effect on the VHCF strength. The fish-eye fracturing process confirmed that most fish-eye fractures arose at sites deeper than the compressive residual stress zone, which did not prevent the creation of the fish-eye, and the fatigue strength improvement in the VHCF range could scarcely be shown as a result of the shot-peening treatment.
\end{abstract}

\section{Hosted file}

manuscript-NM\&Choi-FFEMS-text.pdf available at https://authorea.com/users/386630/articles/ 502075-fatigue-limit-analysis-of-shot-peened-spring-steel

\section{Hosted file}

manuscript-NM\&Choi-FFEMS-Table.pdf available at https://authorea.com/users/386630/articles/ 502075-fatigue-limit-analysis-of-shot-peened-spring-steel

\section{Hosted file}

manuscript-NM\&Choi-FFEMS-Figure.pdf available at https://authorea.com/users/386630/articles/ 502075-fatigue-limit-analysis-of-shot-peened-spring-steel 